\title{
Optimization of Online Learning and Teaching Learning Activities on LMS (Learning Management System) Based Incentives Using Decision Support Systems
}

\author{
Ahmad Yazid ${ }^{1}$ \\ ${ }^{1}$ Faculty of Science and Technology, University of Pembangunan Panca Budi, Medan, Indonesia.
}

\begin{abstract}
Based on data obtained from the E-Learning Bureau of University of Pembangunan Panca Budi, only about $20 \%$ of lecturers want to use LMS or e-Learning portal in the teaching and learning process. Some lecturers use other platforms that they find easier and some use email, WhatsApp Group and flash drives in data transfer or assign assignments to students on the other side. Universities are required to use an online learning platform that can be synchronized with the SPADA DIKTI page so that checking online teaching activities can be monitored or reported periodically and easily. This research will focus on assessing lecturers' activities on online learning at LMS using a Decision Support System where the criteria used are criteria that must be met in the study program accreditation form item. The goal is in addition to increasing the activities of lecturers through incentive giving also directly assisting the study program in the fulfillment of study program form documents. The results of this research will be a reference for the leadership in making policies related to the amount of incentive that will be given as well as other provisions that can stimulate lecturers in increasing teaching and learning activities in LMS or e-Learning portals.
\end{abstract}

Keywords: e-Learning, Learning

Management System, Decision Support System, System Additive Weight, Online Learning System, Online Learning

\section{INTRODUCTION}

There are many public universities and private universities that are engaged in improving infrastructure and changing the system to support the teaching and learning process by utilizing technology as a medium of learning and known as e-Learning.

E-Learning itself is a learning system that utilizes information and communication technology (ICT) that allows students and lecturers to interact without having to face to face by relying on the internet network and LMS (Learning Management System) as an intermediary medium.

The problem that occurs today is that lecturers do not want to use the e-Learning portal to teach for reasons of not understanding how to use it, can not meet learning outcomes and there is no inner attachment between lecturers and students and there is no clear gauge to measure student ethics if done online. Various technical assistance and guidance (BIMTEK) has been carried out by the eLearning bureau but based on activity data in 2017 only about $15 \%$ - $20 \%$ of lecturers who use the e-Learning portal and only 5\% of Law Study Program lecturers who use the e-Learning portal for online learning.

Decision Support System is a system that is able to provide answers to managerial and multicriteria cases, where it is able to provide alternative decisions to leaders in making decisions and making policies for companies. Through the analysis of 
appropriate assessment criteria, this system will be able to provide an alternative to accurate decisions. In this study the criteria are (1) The type of online meeting conducted, (2) The model of teaching materials presented at LMS, (3) The activities of lecturers in LMS or the use of LMS features, (4) Availability of RPS, (5) Completeness of teaching materials, (6) Availability of discussion forums at each meeting session, (7) Availability of Learning Evaluation in each meeting session.

The result of this study is in the form of percentage data of lecturers who actively teach using LMS in each study program from the highest to the lowest. The higher the percentage of lecturers, the more complete the teaching criteria carried out by lecturers and in other words lecturers have met all assessment criteria to get incentive, conversely if the percentage of lecturers is lower then the less criteria met by lecturers but that does not mean this data shows that lecturers do not do the teaching and learning process because it could be that lecturers cannot meet the assessment criteria because lecturers do not understand using LMS. Or e-Learning portal, lecturers can not use electronic media such as laptops, internet and there is a possibility that lecturers do not want to use e-Learning portals because they feel insignificant and not a necessity.

This factor is a reference by the leadership to take a policy on what to do so that lecturers are able to meet all criteria, whether to provide assistance, training, BIMTEK, or make a Rector's policy on rewards for those who meet the criteria of assessment and punishment for lecturers who do not meet the assessment criteria. The policy taken is the absolute decision of the company leader while the decision support system using the SAW method is a system used to assist the leader in collecting, processing and presenting alternative decisions only.

Based on the data of research results, the results of in-depth analysis and alternative based decisions, the manager of a company and in this case is the University of Pembangunan Panca Budi can perform a treatment appropriately to improve the system that damages or interferes with the progress of the University.

\section{LITERATURE REVIEW e-Learning}

E-Learning is a learning method that utilizes information and communication technology in a structured, systematic learning interaction with the best quality. This understanding provides a little picture of the e-Learning system in question, which is where between lecturers and students do not meet face to face (online as a whole) or a combination of conventional systems (face to face) with the online system and often referred to as blinded system. All its components are integrated without any space and time distance (Guidelines for the Implementation of e-Learning University of Pembangunan Panca Budi).

\section{Decision Support System}

Technological developments provide opportunities and opportunities for many of the world's industries to maximize their working time and one of them is when they are faced with important decision-making problems. Decision support systems provide solutions to them because the decision support system itself is flexible, adaptability, and quick answers that can be controlled by the user, even the design of the decision support system allows for communication and coordination between various fields and management levels. From some of the decision-making definition found, that the Decision Support System is an interactive system that supports decisions in the decision-making process through alternatives obtained from the results of data processing, information, model design and parts of computer-based information systems (including knowledge systems) used to support decision making in an organization or company, and he also A decision support system is not a decisionmaking tool, but rather a system that helps 
decision makers by equipping them with information from relevantly processed data and is needed to make decisions about a problem more quickly and accurately. so this system is not intended to replace decision making in the decision-making process (Munarwan and Akhmad Fajar Siddik, 2012). Decision support systems have a very important function for many industries, as they help make decisions to gather and interpret information and build the basis of decision making (Conejar and Haeng, 2014). Other researchers mentioned thatthe decision support system is very beneficial for companies engaged in business for example to help determine the feasibility of a business, they need to conduct several assessments and feasibility studies to improve the quality of the business and help achieve the goalsof the company in question(Yupie Kusumawati,etal, 2012). By using a computer-based decision support system approach, calculations in the financial aspect can be done more clearly so as not to interfere with the smooth running of the business and are expected to improve the process and quality of decision-making results, in this case decisions related to the feasibility assessment of various businesses in the field of manufacturing (Rendra Gustriansyah, 2012).

\section{MATERIALS \& METHODS}

The material that will be used in this research is a decision support system and SAW method with data on lecturer learning activities in LMS (Learning Management System) in the form of readiness of pdf teaching materials, teaching videos, discussion forums, quizzes, assignments, the liveliness of students and lecturers in the teaching and learning process and data of lecturers of social science faculty.

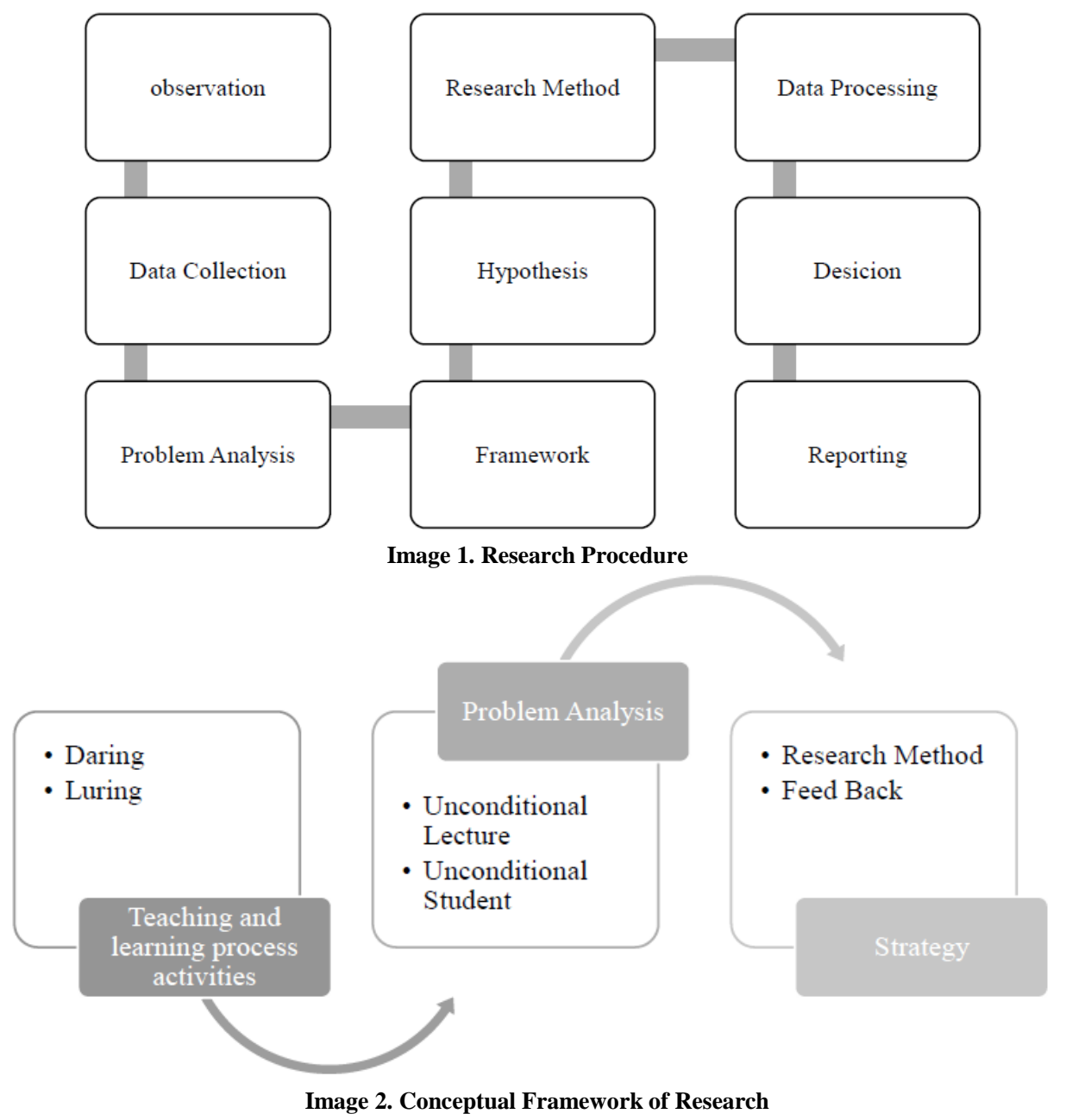


The assessment criteria are as follows, namely:

1. Types of online meetings

2. Types of teaching materials lecturers

3. Activity lecturer at LMS

4. Availability of RPS and college contracts

5. Availability of teaching materials

6. Availability of discussion forums at each meeting
7. Availability of learning evaluation at each meeting

\section{Weight Value}

The weight of values is as follows, namely:

a) Very Good $=3$

b) $\operatorname{Good}=2$

c) Less $=1$

d) Not $\operatorname{good}=0$

Table 1. Criterion weight data

\begin{tabular}{|l|l|l|l|l|l|l|l|l|}
\hline Criterion & Daring & Module & Lecture Strategy & RPS & Module & Discussion & Study Evaluation & Value \\
\hline Criterion Value & 5 & 25 & 20 & 5 & 20 & 5 & 20 & 100 \\
\hline
\end{tabular}

\section{RESULT}

\section{Decision Results of Decision Support System Using SAW Method}

Based on the results available in this

study, there are several policy recommendations that can be considered to be implemented in the University of Pembangunan Panca Budi, namely as follows:

1. Based on the data above, there are 59 lecturers in law programs who use LMS (Learning Management System) or eLearning portal.

2. The results of the Decision Support System using the SAW method found that the average activity of lecturers in the Legal Studies program is at $50 \%$ and this shows that in the Law Study Program lecturers have understood using LMS and have used the e-Learning portal well and continue.

3. The policy that needs to be taken is an incentive division system including the amount that will be received by lecturers must be adjusted to the time and efforts of lecturers who have been devoted to support online learning at UNPAB and regulated in the Rector's Provisions letter.

4. For lecturers who $100 \%$ have used the eLearning portal deserves the reward set out in the provisions of the University.

For lecturers whose percentage is still low, it is necessary to evaluate what obstacles cause them not to use the eLearning portal actively so that they can be searched for troubleshooting as soon as possible.

\section{CONCLUSION}

Based on the results of the above research can be concluded using the Decision Support System using the SAW method obtained data that the average activity of lecturers in the Legal Studies program is at $50 \%$ and this shows that in the Law Study Program lecturers have understood using LMS and have used the eLearning portal well. Another fact is that decision support systems are able to provide alternative decisions based on based on based analysis and accurate assessment systems. The results obtained can be used as a reference to make policies related to rewards and punishments to lecturers, making alternative solutions to increase lecturer activities both for legal studies and for other study programs. This system can also be implemented to all study programs in the University Of Pembangunan Panca Budi so that it can be seen the activities of all lecturers in online learning.

Acknowledgement: None

Conflict of Interest: None

\section{Source of Funding: None}

\section{REFERENCES}

1. Poulymenakin Angeliki, M. Asmina and B. Eleni, "When Instruction meet Design: 
Embeding Instructional Theory Element into e-Learning", The Hermes Newsletter, Issue No 36 (Jan-Feb 2006).

2. Zainal A. Hasibuan and Team. "E-Learning System: Student Centered e-Learning Environment (SCELE)", delivered at a Workshop on e-Learning, November 2007, at UI, Depok.

3. Hari Budi, "e-Learning Development" University of Indonesia, 2017

4. Fitriana N.(2015), "Decision Support System To Determine Students' Academic Achievement by TOPSIS Method". Citec Journal, Volume 2, No. 2.

5. Jamila. (2011), "Subcontracting Election Decision Support System Using Entropy and TOPSIS Methods". Journal of IJCCS, Vol. 5. No.2.

6. Ikmah. (2016),"The Support System for The Selection of Lecturer Admissions Results Using the TOPSIS Method". Journal of SNTIM, Vol. 1, No. 1.

7. Leha Kurniasih D.(2013),"Laptop Selection Decision Support System with TOPSIS Method". Jurnal Pelita Informatika Budi Darma, Vol 3, No. 2.

8. Mohamed Rosmayati. (2010),'Decition Support System (DSS) in Construction Tendering Processes". International Journal of Computer Science Issues, Volume 7, Nomor 1.

9. Rajalakshmi K. Dan Mohan Chandra S.(2011),'Decition Support System in Healthcare Industry". International Journal of Computer Application, Volume 26, Nomor 9.

10. Oktariani I. and Jauhari J.(2011), "MobileBased Decision Support System for Working Capital Determination (KMK) at a Bank". Journal of Information Systems (JSI), Vol. 3, No.1.

11. Puspitasari L.(2013),"Application of Profile Matching Method in Employee Performance Assessment Decision Support System (Case study: PT. Plantation Nusantara III Medan".
Informatics Lamp Budi Darma, Volume: V, Number: 3.

12. Velmurugan Senthil M.(2011), "Aplication of Decition Support System in ECommerce". Communication of the IBIMA Vol 5, No. 1.

13. Munawarman, Fadjar Siddik A.(2012), "Decision Support System Using TOPSIS Method". Journal of Information Systems (JSI), Vol. 4, No.1.

14. Shrikhrisna. (2014), “A New Car Selection in the Market using TOPSIS". International Journal of Enginering Research and General Science, Vol 5, No. 1.

15. Widyaningsih Maura. (2016),"Determination of Student Competency Competition Participants Using Simple Additive Weighting (SAW)". Journal of Informatics and Computers (JIKO), Volume: 1, Number: 1.

16. Alwi H.(2015),"Premises Assessment Decision Support System at CIMB Niaga Medan Bank Using AHP Method". Journal of Informatics Budi Darma, Volume: IX, Number: 2.

17. Wulan Sari B.(2015),"Comparison of Profile Matchig and Simple Additive Weighting Methods in Determining The Majors of Students of Class X High School N.2 Ngalik". Scientific Journal of DASI, Volume: 6, Number: 1.

18. Magdalena Hilyah. (2015),"Decision Support System to Determine the Best Graduate Students in College (STMIK Atma Luhur Pangkalpinang Case Study)". National Seminar on Information and Communication Technology (SENTIKA), Volume: 1, Number: 1.

How to cite this article: Yazid A. Optimization of online learning and teaching learning activities on LMS (learning management system) based incentives using decision support systems. International Journal of Research and Review. 2021; 8(10): 225-229. DOI: https://doi. org/10.52403/ijrr.20211029 